\title{
REVIEW
}

\section{Current Standing of Longleaf Pine Trees under Climate Change}

\section{Kimberly A. Bowman* Xiongwen Chen}

Department of Biological and Environmental Sciences, Alabama Agricultural and Mechanical University, Normal, AL 35762, U.S.

\section{ARTICLE INFO}

Article history

Received: 12 January 2022

Accepted: 19 January 2022

Published Online: 26 January 2022

\section{Keywords:}

Longleaf pine

Climate change

Reproduction

Growth

Conservation

Dendrochronology

Cone production

\begin{abstract}
Climate change poses many risks to economically and ecologically crucial species. Longleaf pine (Pinus palustris Mill.) trees are keystone species that were once dominant across the southeastern United States, but now occupy less than $5 \%$ of their historic range and are thus classified as endangered. Here we review the current status and challenges facing longleaf pine trees, what is known on how changing climate will impact longleaf growth and reproduction, and gaps in the literature that are important to address. We found that many fundamental aspects of longleaf pine growth and reproduction are understood. However, these systems are complex, and not all is known about each factor that influences the relationship between climate, growth, and reproductive output. Additionally, long-term data sets capable of examining all relevant factors in these relationships do not currently exist. To fill necessary gaps, we recommend a joint approach between using readily available data sets and establishing new long-term monitoring plots targeted to collect data on missing or poorly understood conditions. This review provides a clue from an ecological complexity perspective to understand and manage longleaf pine forests under climate change.
\end{abstract}

total number of days above or below a certain temperature threshold, frequency of high-intensity events such as hurricanes or droughts, and many others ${ }^{[4-6]}$. Moreover, changing climate can affect plant communities on both short-term and long-term scales ${ }^{[1]}$. However, each taxon responds differently to changes in each variable, and much is still not understood about how a globally changing climate will affect every plant species ${ }^{[1,7-9]}$. More genetically or spatially malleable species may adapt

\footnotetext{
*Corresponding Author:

Kimberly A. Bowman,

Department of Biological and Environmental Sciences, Alabama Agricultural and Mechanical University, Normal, AL 35762, U.S.; Email: kimberly.bowman@bulldogs.aamu.edu
} 
or experience range shifts, while more constrained species may face extinction ${ }^{[7,10]}$. Vincent et al. ${ }^{[11]}$ supported that rarer (i.e., less widespread) wild plant species were less resilient to changing temperatures and precipitation than their more common counterparts, possibly due to their inherently more constrained niche.

In the southeast United States, climatologists anticipate a continued increase in temperatures and higher variability in precipitation, with a greater occurrence of extreme precipitation events such as hurricanes ${ }^{[12]}$. Regional variability is expected as well, and confounding factors in many locations will result in increased drought stress ${ }^{[4,13]}$. This has many implications for forest ecosystems since climate impacts the dynamics of both trees and stand success, although how can vary drastically by species ${ }^{[14-}$ ${ }^{16]}$. Climate change thus poses many new questions of how endangered plant species will transform over time.

Southeastern pine trees have been massive sources of profit for hundreds of years, and once produced the greatest amount of rosin and turpentine ever harvested globally ${ }^{[17]}$. Even still, southeastern US pine plantations produce $16 \%$ of the world's industrial wood supply ${ }^{[18]}$. This does not include the economic benefits of practices such as agroforestry or nontimber products, which can significantly enhance the value of land ${ }^{[19-20]}$. Current sources of profit are largely from pine plantations of more frequently selected for species such as shortleaf pine (Pinus echinata Mill.), slash pine (Pinus elliottii Engelm. var. elliottii), and loblolly pine (Pinus taeda L.). However, one less widespread species, longleaf pine (pinus palustris Mill.), has been the subject of growing interest and concerted restoration efforts over the last few decades ${ }^{[21,22]}$.

In the time before European settlement, longleaf pine savannas covered 60-90 million acres or more across the southeastern United States, running northsouth from Virginia to Florida and as far west as Texas ${ }^{[17,21]}$ (Figure 1). An estimated $62 \%$ of this area was dominated singularly by longleaf pine trees ${ }^{[17]}$. However, following colonization, southeastern pine trees were widely depleted due to over-harvesting of naval stores and timber. Increasing land-use change, along with other factors prevented the reestablishment of much of previously forested areas ${ }^{[17]}$. Even more so than its counterparts, longleaf pine experienced lower success in reestablishment due primarily to suppressed fire regimes and young tree predation from nonnative feral hogs ${ }^{[17]}$. This, along with other factors such as sporadic seed crop production and selection for other pine species for use in pine plantations, has resulted in a current longleaf pine coverage of less than $5 \%$ of its historical range, and both the tree and ecosystem are classified as endangered ${ }^{[17,21]}$.
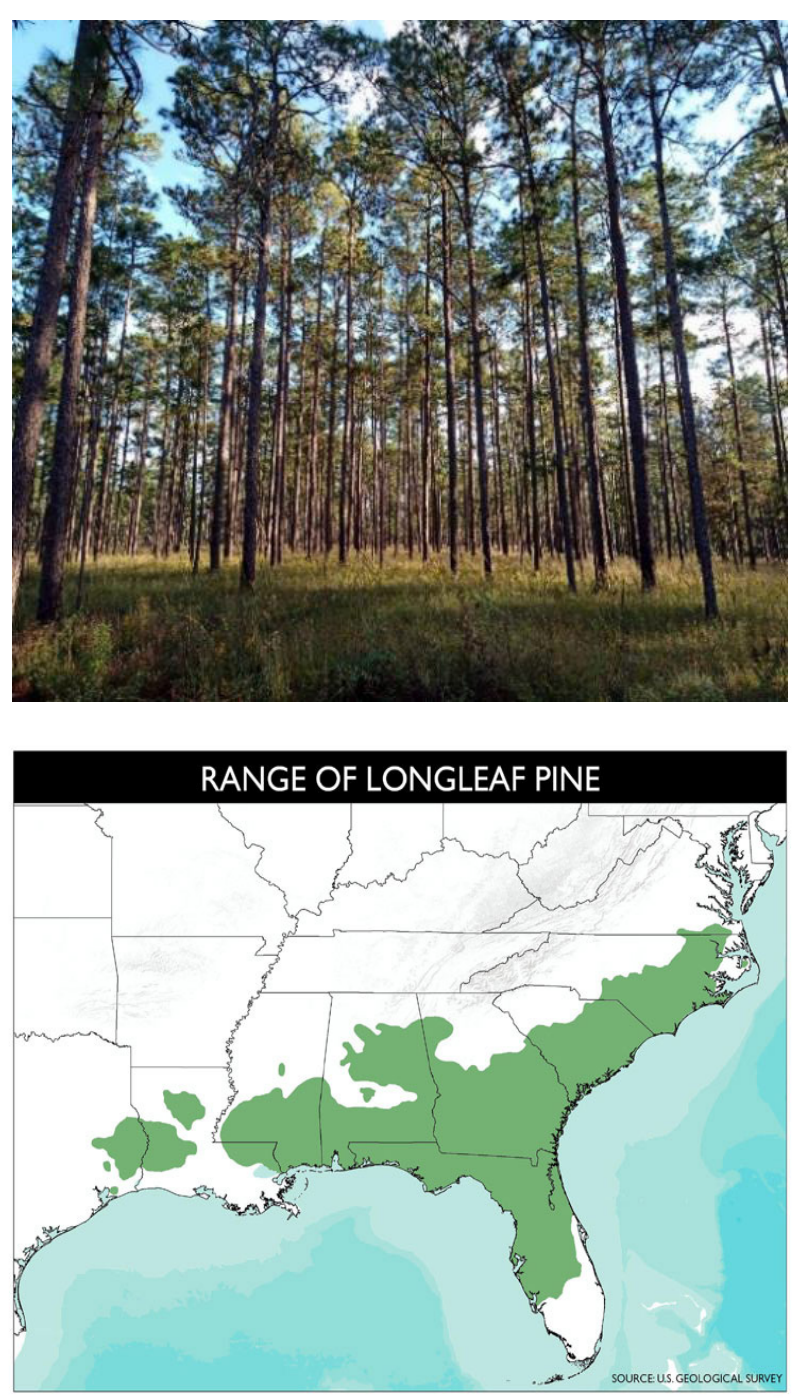

Figure 1. Longleaf pine forests and the pre-settlement range.

Despite the high fragmentation and poor quality of remaining stands, longleaf forests still hold much ecological and commercial value ${ }^{[21,23]}$. Commercially, longleaf pine trees produce a high-quality wood that is likely more resilient to damage due to natural stressors such as drought ${ }^{[18,24,25]}$. Longleaf stands are also ideal for alternative sources of revenue, such as pine straw and wildlife leases ${ }^{[17]}$. Ecologically, longleaf trees remain keystone and indicator species when dominant in the canopy ${ }^{[21,26]}$. Remaining longleaf ecosystems host some of the highest levels of biodiversity in North America, and are home to many endemic species that now face declines due to habitat loss ${ }^{[17,21,23]}$. Perhaps most highlighted of these is the federally endangered red-cockaded woodpecker (Picoides borealis Vieillot), which acts as a keystone species due to its unique ability to create cavities in still living trees ${ }^{[27]}$. Environmentally, pine forests act as 
carbon sinks, even more so than hardwood forests, and even when managed through frequent burning ${ }^{[28]}$. It has even been suggested that longleaf pine ecosystems have the greatest potential for carbon storage of southeastern pines given their life history, commercial use, and ecological characteristics ${ }^{[29]}$.

Most remaining longleaf ecosystems are altered beyond their resiliency and require human intervention to survive ${ }^{[17]}$. In the latest US Forest Service report on longleaf pine forest conditions, Oswalt et al. ${ }^{[21]}$ report that the primary cause of mortality in longleaf pines is damage from weather events (eg. windthrow, lightning). However, altered fire regimes, high levels of fragmentation and disturbance from invasive species, as well as limited amounts of harvesting for timber may also impact stand success ${ }^{[21]}$. However, much is still not understood about how climate change will impact each of these factors, as well as the trees themselves. If climate change can affect environmental, conservational, and economical sectors of forest ecology, and longleaf pine is a crucial southeastern species, then more must be known about how changing climate will impact longleaf pine success ${ }^{[30-32]}$. Here we outline what is known and highlight existing gaps in our current understanding of how climate change is expected to impact longleaf pine growth and reproduction, two key metrics for conservation.

\section{Climate and Longleaf Pine Growth}

Longleaf pine grows from April through October in its northernmost areas of range to almost year-round nearer to the equator, where growth intermittently stagnates in the months of January through February ${ }^{[33,34]}$. It is characterized by slower early-stage growth than many other cooccurring pine species, due to its formation of a grass stage that is not shared with other southern pines ${ }^{[17,22]}$. This stage acts as a trade-off, however, as it significantly increases the ability of individuals to survive lowintensity fires that otherwise kill off competitor trees ${ }^{[21,35]}$. Without the competition of fire, longleaf pine will often be outgrown and outcompeted by other tree species ${ }^{[17]}$.

Much about the relationship between climate and growth of longleaf trees comes from correlative studies using dendrochronological records ${ }^{[34,36,37]}$. Dendrochronology is a well-purported dating method capable of determining growth, climate, disturbance, and anthropogenic histories from living trees and preserved wood ${ }^{[38,39]}$. Advances in dendroclimatology allow for higher resolution in determining spatial and temporal patterns from tree ring data ${ }^{[9]}$. However, growth responses to climate variables differ widely between species and potentially over time ${ }^{[9,33,40]}$. Although many datasets only consider total annual tree growth, total wood (TW) is comprised of two parts: earlywood (EW, spring growth) and latewood (LW, summer and fall growth) ${ }^{[6,34]}$. Speciesspecific EW and LW growth each often correlate with seasonal climate variables and therefore allow for a more complete climate history ${ }^{[6,41]}$. However, difficulties in distinguishing seasonal growth factors can arise given the confounding relationship between interannual EW and LW growth, which is also known to differ between species. This variation, along with other physiological factors, can determine how useful a species is in establishing chronologies ${ }^{[34,41]}$.

Longleaf pine is a quality dendroclimatological species given its historical abundance, slow decay, climactic sensitivity, and long lifespan ${ }^{[33]}$. Multiple centurieslong chronologies from longleaf growth rings have been produced ${ }^{[34,36,37]}$. Another useful characteristic of longleaf pine is that the transition from EW to LW is characteristically discrete and occurs relatively consistently between May and June ${ }^{[33,34]}$. In longleaf pine rings, EW is much less sensitive to climate than LW; studies have found weak to no correlation between EW growth and climate variables ${ }^{[34,37]}$. Interestingly, Stambaugh et al. ${ }^{[34]}$ reported that EW growth was correlated to the previous year's LW growth as suspected, but that changes in sign occurred over time. However, EW growth does vary annually, and there are irregular strong to insignificant positive correlations between EW and LW growth in the same year ${ }^{[34,37]}$. Thus, Soulé et al. ${ }^{[37]}$ found that the best chronologies are obtained from LW growth that is adjusted to remove the influence of EW trends.

Multiple studies have reported on the strength of late summer and early fall climate correlations to longleaf radial growth ${ }^{[34,37]}$. Soulé et al. ${ }^{[37]}$ found a positive correlation between growth and mean temperature during the first half of the year (weaker) that switched to negative around June (stronger) when the transition to latewood occurs. Multiple studies have found positive and negative growth correlations to annual precipitation and temperature, respectively ${ }^{[34,37,42]}$. In studies that partitioned TW into EW and LW, these correlations were strongest in the late summer/early fall ${ }^{[34,37]}$ (Figure 2). Furthermore, the frequency of high-intensity precipitation events such as hurricanes are positively correlated with LW growth, and can even produce stronger correlations than a greater total amount of precipitation from lower-intensity events ${ }^{[6,37]}$.

Significant gaps still exist in our understanding of climate-related variation in longleaf pine radial growth. For example, Ames et al. ${ }^{[42]}$ inexplicably found that the individually detrimental effects of fire and 


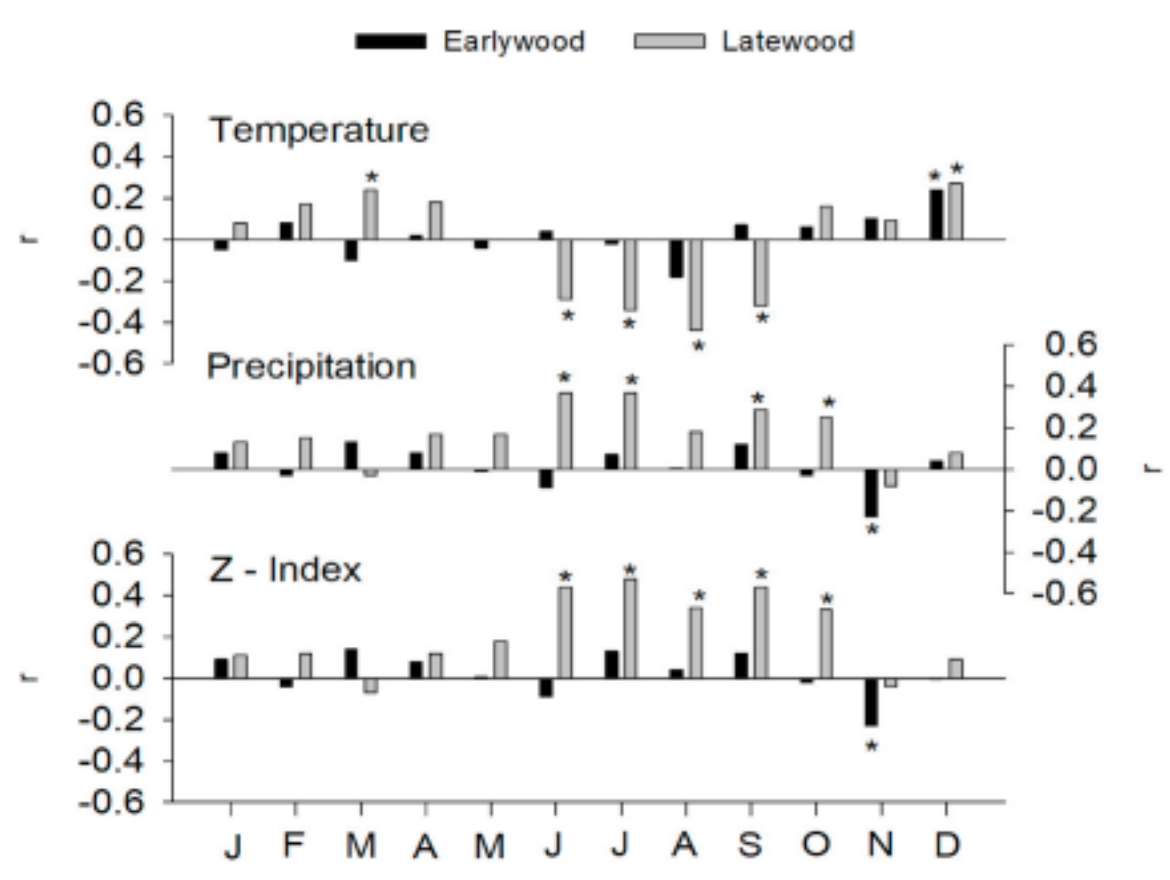

Figure 2. Earlywood and latewood correlation coefficients for monthly temperature, precipitation, and Palmer Z-Index from longleaf pine wood. Earlywood and latewood tree-ring chronologies. Stars indicate statistical significance at the $\alpha=0.05$ level. From Stambaugh et al., 2021 .

high temperatures on growth can mitigate each other. Additionally, a growing number of studies have begun to challenge basic assumptions in our understanding of longleaf growth. Loudermilk et al. ${ }^{[43]}$ found that, in opposition to conventional knowledge, the presence of midstory oak trees on xeric sites can facilitate the survival of longleaf pine seedlings, likely due in part to the reduction of low soil moisture stressors. However, given competition of other resources, more must be studied on how early growth rates (e.g., biomass accumulation) or growth of longleaf pines on wetter sites may be impacted. Furthermore, the ease of climate manipulation for younger trees along with a focus on longleaf reestablishment in research has led to an overabundance of experimental studies on seedlings and saplings, and fewer studies exist that manipulate climate variables for whole stands of mature trees ${ }^{[44-46]}$. When experimental manipulation is conducted on mature stands, methodology is limited to what is spatially and environmentally possible; Samuelson et al. ${ }^{[12]}$, for example, lowered soil water content by throughfall exclusion troughs but were still constrained by naturally occurring drought conditions. Moreover, given the known variation in response to climate across longleaf pine range, as well as the limited geographical extent of most chronologies, more analyses are needed to evaluate if each of these patterns is universally true rather than sitespecific.

\section{Climate and Longleaf Pine Reproduction}

Although fundamentals of longleaf pine reproduction are generally understood, many factors related to climate variability are not ${ }^{[47]}$. Longleaf pines are wind-pollinated and monoecious ${ }^{[35]}$. The reproductive cycle lasts approximately 3 years from the time reproductive strobili begin to form until seed dispersion occurs (Figure 3$)^{[48]}$. Seed production is temporally variable; masting cycles have been contradictorily reported over average time frames from 3-10 years, and are now understood to vary spatially ${ }^{[47-49]}$. Physiologically, the resource accumulation hypothesis suggests that masting species, characterized by periods of low seed productivity followed by periods of booms, spend multiple years accumulating resources until a threshold is reached, allowing for large seed production ${ }^{[50]}$. Chen et al. ${ }^{[50]}$ found evidence for weak phase coupling, yet this varied between sites and only occurred during certain time periods. Thus, longleaf pine is not a strong masting species. Recent work by Chen et al. ${ }^{[51]}$ presented burstiness - strong intermittent activity between longer periods of lulls - of longleaf cone production as a new method for potentially helping to compare and predict the timing of good seed crop years between longleaf pine stands. Many factors such as genetics and site characteristics have been studied and shown to impact these reproductive trends, but relationships with climate are often complex and not fully understood ${ }^{[47,52,53]}$. 


\section{Cone Chronology}

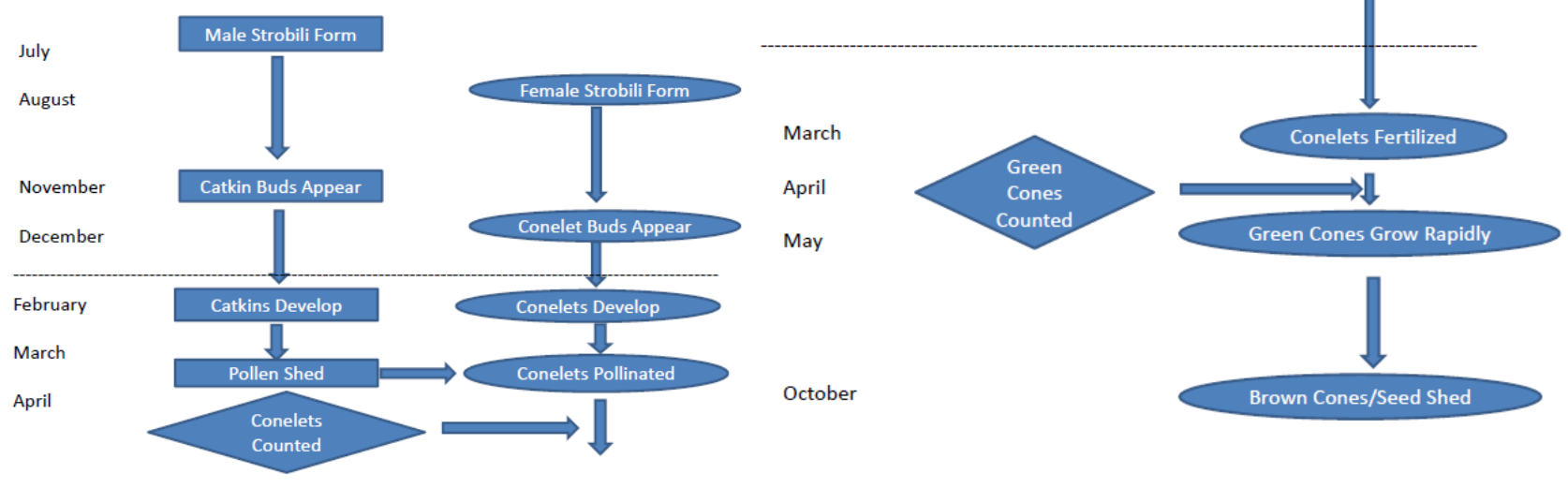

Figure 3. The cone chronology of longleaf pine.

\subsection{Pre-fertilization Trends}

As climate changes over time, reproductive phenology, a branch of biology focused on the timing of yearly reproductive cycles, will become increasingly important ${ }^{[54]}$. In botany, both the timing of growing seasons and reproduction are known to vary with climate ${ }^{[33,55]}$. Factors associated with reproduction in plants such as time of pollen release, fertilization, and intraspecific interactions are known to vary by species, and the impact of climate on these factors varies as well ${ }^{[1,5,56,57]}$. For example, in angiosperms, changing temperature variables can lead to altered seasonal timing between plant flowering and pollinator activity and composition ${ }^{[54]}$. Limited studies have been conducted on longleaf pine phenology as it relates to climate change. Historical research on reproductive influences supports that weather patterns such as precipitation influence early reproductive structure success, and that mismatched favorable conditions between male (catkin) and female (conelet) structures can lead to heavy losses before fertilization ${ }^{[35,49]}$. Although pollen and unfertilized conelets do not have a temporal cycle, the sex allocation ratio between male and female structures is positively correlated with temperature, and cone production is optimal when this ratio is intermediate ${ }^{[26]}$. Chen et al. ${ }^{[5]}$ revealed no significant trend in either the time of peak pollen shedding or time of $80 \%$ accumulated pollen density over 55 years of data. However, the time of peak pollen shedding was connected to climate factors, primarily the heat sum of total days above $0{ }^{\circ} \mathrm{C}$. Stambaugh et al. ${ }^{[34]}$ and Rother et al. ${ }^{[33]}$ both rely on the importance of seasonality of longleaf growth for dating significant environmental findings. But more information is needed to fully understand how future conditions will affect the timing of peak longleaf growth and reproduction.

\subsection{Trends in Cone Production}

Cone production, the commonly held metric for quantifying longleaf reproductive success, is supported to be both self-organized and self-similar, given that it significantly follows power laws ${ }^{[58,59]}$. Oftentimes, correlations between climate and cone production are localized rather than universally held ${ }^{[47,48]}$ (Figure 4). Many longleaf sites have seen increased cone production over the past 40 years, but there is not a universally strong link between cone production and climate ${ }^{[48,59]}$. Chen et al. ${ }^{[47]}$ found no long-term trend in the coefficient of variation (CV) of cone production, although there were fluctuations and several sudden breaks present. They also reported a slight positive correlation of $\mathrm{CV}$ with average air temperature and localized correlations with precipitation. When looked at from the perspective of multiscale entropy there is a correlation between the complexity of cone production and the complexity of local climate variables ${ }^{[60]}$. Guo et al. ${ }^{[48]}$ examined climate variables during the 3 -year reproductive cycle of longleaf pines and found that correlations varied by location and grew weaker with increasing distance between sites. Typically, higher cone production was correlated to sites with moderate climates, as well as a warmer July \& August and wetter October $\&$ November directly preceding seed fall ${ }^{[48]}$. Despite advancements in research, unexplained variation in cone production still exists between and within sites. Given the lack of data on longleaf pine resource allocation, quantifying internal factors of resource allocation (e.g. biomass allocation) as they relate to climate variables may be a key step to strengthening our understanding of the mechanisms behind sporadic longleaf cone production ${ }^{[5]}$. 


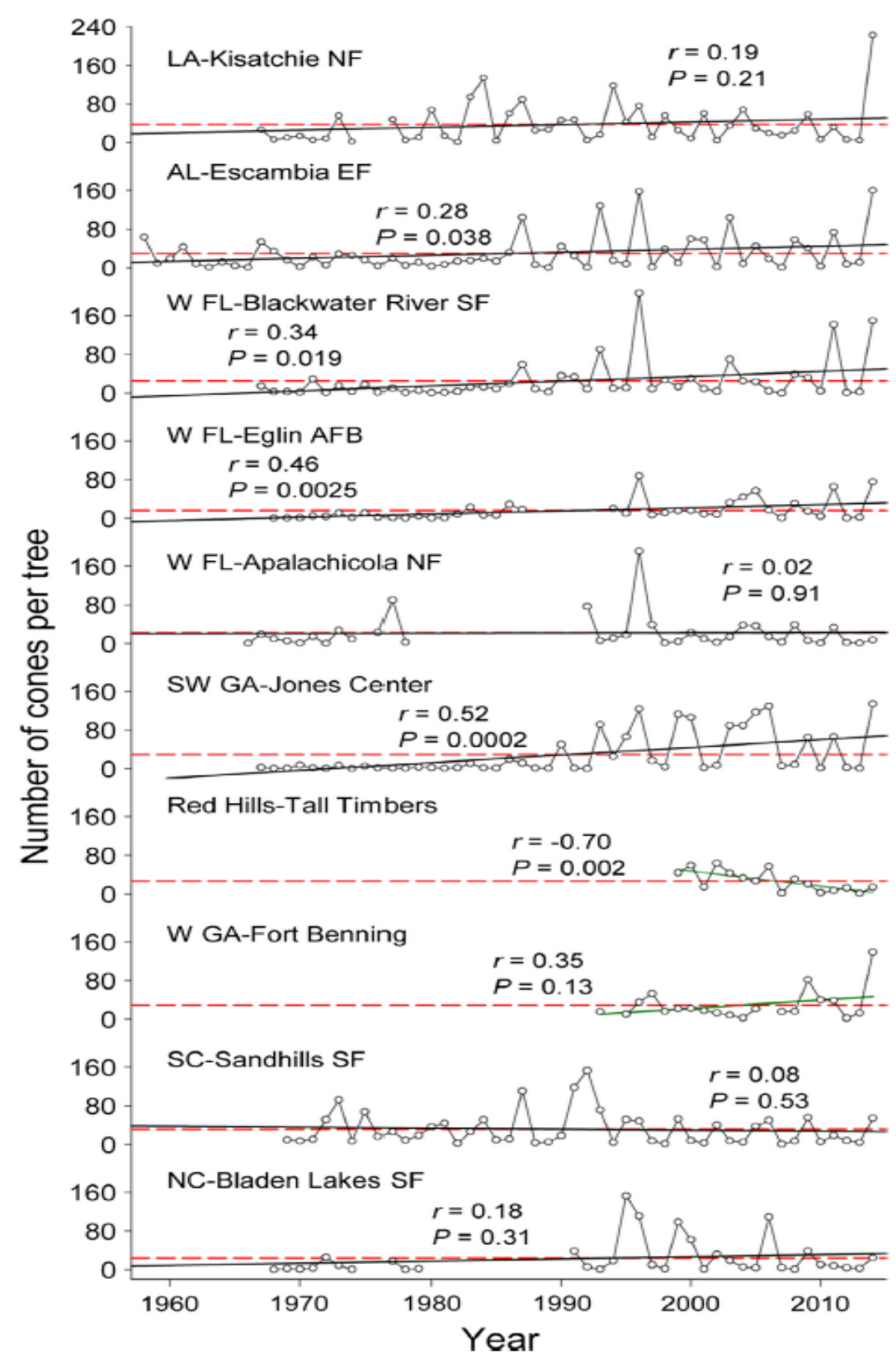

Figure 4. Long-term annual cone production at 10 sites across the longleaf pine range using USFS cone data. From reference ${ }^{[48]}$

\section{Other Considerations}

Wildfire is a substantial factor in longleaf reestablishment and maintenance ${ }^{[17,21,52]}$. Without the presence of frequent fires, faster-growing yet less fire-resistant hardwoods and other pine species are prone to outgrow and outcompete longleaf pine ${ }^{[17]}$. Central to this issue is that wildlife regimes throughout the southeast have been anthropogenically drastically reduced since times of pre-European settlement ${ }^{[17,21]}$. However, relationships between fire, anthropogenic activity, climate, and energy storage can be complex, and not all is known about each factor ${ }^{[52,61]}$. For instance, the grass stage unique to longleaf pine allows for high survivability of low-intensity fires, yet may represent a trade-off with lowered survivability to drought stress than other pines such as loblolly ${ }^{[35,44]}$. Despite this, longleaf pine is generally thought to be more drought-resistant than other southern pines given its ability to survive on xeric sites where others cannot, and physiological factors such as a prominent taproot at maturity ${ }^{[4]}$. Yet it is not known at what exact point saplings transition into developing longer taproots, or if changing environmental conditions 
drive them to do so at different stages. The knowledge that genetic plasticity has been documented in longleaf pines sourced across its range ${ }^{[62]}$ presents further opportunities for study. Furthermore, more could be known on how management practices of prescribed burning will impact these and carbon storage factors. To understand the role of climate on longleaf conservation, more research is needed on these interactions.

Gaps in knowledge become more confounded when considering the lack of understanding of seed predators, which may play a role in reproductive cycles ${ }^{[63,64]}$. Although longleaf pine is not a strong masting species, cycles of lesser cone production followed by periods of booms have been noted for decades ${ }^{[17,47,48]}$. The primary hypothesis for causality of masting in trees, predator starvation and satiation, thus may still apply. This hypothesis holds that the causality of masting is based on extended times of low seed crop reducing predator populations to a point below what can consume the majority of seeds during a boom ${ }^{[63,65]}$. Recent findings have indicated that the taxonomy of predator species can play a critical role in the effectiveness of masting ${ }^{[66-}$ ${ }^{68]}$. However, the bulk of studies on masting and seed predation focus on strong masting species ${ }^{[63,66-68]}$. In longleaf pine trees, the study of the predator starvation and satiation hypothesis is hindered by the lack of a foundational understanding of species distributions and primary drivers of predation pressure. Historical studies have documented fallen longleaf seed predation by insects, small and large mammals, and birds, but many can date back multiple decades ${ }^{[69-72]}$. Recent localized studies have begun to contradict historical findings in who among these groups are the primary predators (see Willis et al. ${ }^{[73]}$ ). Especially considering that wildlife populations can change over time and range, comprehensive datasets capable of connecting masting cycles to predation pressure thus do not exist for longleaf pine. In order to reasonably predict how longleaf pine phenology will impact restoration success, more must be known about how or if seed predators impact reproductive cycles.

It is generally held that, given limited environmental resources, resource allocation to life-history traits such as reproduction and growth should be inversely related as trade-offs ${ }^{[7,75]}$. However, plant expression of resource allocation can vary over species, location, and time ${ }^{[76-}$ ${ }^{78]}$. Environmental conditions such as water and nutrient availability are crucial for allocation dynamics, and plants change strategies in response to changing climate conditions ${ }^{[7,80]}$. When placed under intensive distress from pests or drought, for example, trees may choose to devote most of their remaining resources to either survival or reproduction at the cost of the other ${ }^{[79]}$. In longleaf pine trees, there is generally a weak negative correlation between cone production and radial growth, but this relationship is largely overshadowed by the influence of other variables such as stand density ${ }^{[81,82]}$. However, there is often a complex interplay between climate, resource availability, and plant success ${ }^{[83,84]}$, and much must still be understood about reproductive allocation in longleaf pine. For example, frequent, low-intensity burns can hinder growth in the short term ${ }^{[42]}$. Trees burned more frequently and those higher in more open canopies produce more cones, but when conspecific density is high, larger trees have more reproductive success ${ }^{[42]}$. Holistic research incorporating data on many relevant factors is needed to understand reproductive allocation in any system, and for longleaf pine, sufficient data sets do not always exist. Moreover, given the many reported findings of intersite variation in longleaf growth and reproduction ${ }^{[47,48,82]}$, localized approaches will be necessary.

\section{Challenges and Future Directions}

Although short-term studies on the ecophysiological response of longleaf pine seedlings to environmental change exist ${ }^{[17,44]}$, results may be hard to apply for mature trees. We suggest that long-term in-field monitoring at the ecosystem level should be set up in order to better understand the dynamics of tree growth, cone production, and environmental change. This monitoring should include climate, atmospheric conditions (e.g., $\mathrm{CO}_{2}$ concentration and nitrogen deposition rate), soil (e.g., water, nutrients), intrinsic factors (such as photosynthesis), and interactions with other plants (shrubs and grasses). The original pollen observation should be continued. With this long-term monitoring data, the ecological mechanisms related to tree growth and cone production could be discovered. A shortcoming of this research is its likelihood to be cost-prohibitive; for example, photosynthesis (evapotranspiration) of an entire mature tree is hard to measure. Maintaining periods of prescribed burning every three years can also make it complicated for long-term monitoring (e.g., instrument takeoff and re-installation).

Using currently available information and developing modeling or conducting data analysis will be another way to understand the interactions between climate and longleaf pine growth and reproduction. So far, use of US Forest Service cone data has allowed for many studies on influential factors of longleaf reproduction ${ }^{[47,48,50,59,60]}$. The advantage of this approach is low cost, but the shortcoming is the limited amount of needed information that already directly available. The objectives of the models or data analysis need to be refined by experts in 
this field.

Thus, a compromise between the above two approaches may be practical, such as setting up important instruments at some study sites for well-developed ideas in long term. In addition, some specific funding opportunities should be available.

\section{Conclusions}

Longleaf pine is a keystone species with significant commercial, ecological, and environmental benefits in the southeastern United States. Yet changing climate poses significant risks to many factors of forest ecology. We present here a limited scope of the current understanding of climate relationships with factors of success of longleaf pine. Growth and reproduction are perhaps two of the most important of these metrics, but not all is known about the fundamental mechanisms behind them. To fully understand and adapt for longleaf pine conservation more holistic and localized research is necessary.

\section{Acknowledgments}

This research was supported by the USDA National Institute of Food and Agriculture Capacity Building Program (2021-38821-34596) and the McIntire Stennis project (1008643).

\section{Author Contributions}

$\mathrm{KAB}$ wrote the manuscript and $\mathrm{XC}$ provided the ideas and necessary information. Both improved the manuscript.

\section{References}

[1] Martin, G., Devictor, B., Motard, E., Machon, N., Porcher, E., 2019. Short-term climate-induced change in French plant communities Biology Letters. 15(7), 2019028.

[2] Thuiller, W., Lavorel, S., Araújo, M.B., Sykes, M.T., Prentice, I.C., 2005. Climate change threats to plant diversity in Europe. Proceedings of the National Academy of Sciences of the United States of America. 102(23), 8245-50.

DOI: https://doi.org/10.1073/pnas.0409902102.

[3] Iverson, L., McKenzie, D., 2013. Tree-species range shifts in a changing climate: detecting, modeling, assisting. Landscape Ecology. 28, 879-889.

DOI: https://doi-org.aamu.idm.oclc.org/10.1007/ s10980-013-9885-x

[4] Allen, C., Breshears, D., McDowell, N., 2015. On underestimation of global vulnerability to tree mortality and forest die-off from hotter drought in the Anthropocene. Ecosphere. 6(8), 129.
DOI: http://dx.doi.org/10.1890/ES15-00203.1

[5] Chen, X., Brockway, D., Guo, Q., 2020.Temporal patterns of pollen shedding for longleaf pine (Pinus palustris) at the Escambia Experimental Forest in Alabama, USA. Dendrobiology. 84, 30-38.

[6] Mitchell, T., Knapp, P., Patterson., T., 2020. The importance of infrequent, high-intensity rainfall events for longleaf pine (Pinus palustris Mill.) radial growth and implications for dendroclimatic research. Trees, Forests and People. 1, 100009.

DOI: https://doi.org/10.1016/j.tfp.2020.100009.

[7] Bakkenes, M., Alkemade, J.R.M., Ihle, F., Leemans, R., Latour, J.B., 2002. Assessing effects of forecasted climate change on the diversity and distribution of European higher plants for 2050. Global Change Biology. 8, 90-407.

DOI: https://doi.org/10.1046/j.1354-1013.2001.00467.x

[8] Chen, X., Niu, J., 2020. Evaluating the Adaptation of Chinese Torreya Plantations to Climate Change. Atmosphere. 11(176).

DOI: https://doi.org/10.3390/atmos11020176.

[9] Copeheaver, C., Shumaker, K., Butcher, B., Hahn, G., Perkins, L., Dukes, C., Thompson, E., Pisaric, M., 2020. Dendroclimatology of sugar maple (Acer saccharum): Climate-growth response in a late-successional species. Dendrochronologia. 63.

DOI: https://doi.org/10.1016/j.dendro.2020.125747.

[10] Jump, A.S., Penuelas, J., 2005. Running to stand still: adaptation and the response of plants to rapid climate change. Ecology letters. 8(9).

DOI: https://doi.org/10.1111/j.1461-0248.2005.00796.x

[11] Vincent, H., Bornard, C., Kempel, A., Fischer, M., 2020. Rare species perform worse than widespread species under changed climate. Biological Conservation. 246.

DOI: https://doi.org/10.1016/j.biocon.2020.108586.

[12] Samuelson, L., Stokes, T., Ramirez, M., Mendonco, C., 2019. Drought tolerance of a Pinus palustris plantation. Forest Ecology and Management. 451. DOI: https://doi.org/10.1016/j.foreco.2019.117557.

[13] Castillo, A., Goldfarb, B., Johnsen, K., Roberds, J., Nelson, C., 2018. Genetic variation in Water-Use Efficiency (WUE) and growth in mature longleaf pine. Forests. 9(11). DOI: https://doi.org/10.3390/f9110727.

[14] Brandl, S., Paul, C., Knoke, T., Falk, W., 2020. The influence of climate and management on survival probability for Germany's most important tree species. Forest Ecology and Management. 458.

DOI: https://doi.org/10.1016/j.foreco.2019.117652.

[15] Pretzsch, H., Biber, P., Schütze, G., Uhl, E., Rötzer, 
T., 2014. Forest stand growth dynamics in Central Europe have accelerated since 1870. Nature Communications. 5(4967).

DOI: https://doi.org/10.1038/ncomms5967

[16] Vaz Monteiro, M., Levanič, T., Doick, K., 2017. Growth rates of common urban trees in five cities in Great Britain: A dendrochronological evaluation with an emphasis on the impact of climate. Urban Forestry \& Urban Greening. 22, 11-23.

DOI: https://doi.org/10.1016/j.ufug.2017.01.003.

[17] Jose, S., Jokela, E., Miller, D., 2006. The Longleaf Pine Ecosystem. DOI: https://doi.org/10.1007/978-0-387-30687-2_1.

[18] Samuelson, L., Stokes, T., Johnsen, K., 2012. Ecophysiological comparison of 50-year-old longleaf pine, slash pine and loblolly pine. Forest Ecology and Management. 274, 108-115.

DOI: https://doi.org/10.1016/j.foreco.2012.02.017.

[19] Burner, D., Dwyer, J., Godsey, L., 2011. Stocking rate mediates responses of mid-rotation loblolly pine in west-central Arkansas. Agroforestry Systems. 81, 287-293.

DOI: https://doi-org.aamu.idm.oclc.org/10.1007/ s10457-010-9326-7

[20] Susaeta, A., Gong, P., Adams, D., 2019. Implications of the reservation price strategy on the optimal harvest decision and production of nontimber goods in an even-aged forest stand. Canadian Journal of Forest Research. 50(3), 287-296.

DOI: https://doi.org/10.1139/cjfr-2019-0213

[21] Oswalt, C., Cooper, J., Brockway, D., Brooks, H., Walker, J., Connor, K., Oswalt, S., Conner, R., 2012. History and current condition of longleaf pine in the Southern United States. Gen. Tech. Rep. Asheville, NC: U.S. Department of Agriculture Forest Service, Southern Research Station. pp. 51.

[22] Oswalt, S., Smith, W., Miles, P., Pugh, S., 2014. Forest Resources of the United States, 2012: a technical document supporting the Forest Service 2010 update of the RPA Assessment. Gen. Tech. Rep. WO91. Washington, DC: US Department of Agriculture, Forest Service, Washington Office. 218, 91.

[23] Noss, R., LaRoe, E., Scott, J., 1995. Endangered ecosystems of the United States: a preliminary assessment of loss and degradation. USDI National Biological Service, Biological Report 28, Washington DC.

[24] Addington, R., Donovan, L., Mitchell, R., Vose, J., Pecot, S., Jack, S., Hacke, U., Sperry, J., Oren, R., 2006. Adjustments in hydraulic architecture of Pinus palustris maintain similar stomatal conductance in xeric and mesic habitats. Plant, Cell \& Environment.
29, 535-545.

DOI: https://doi.org/10.1111/j.1365-3040.2005.01430.x

[25] South, D., 2006. Planting longleaf pine at Wide Spacings. Native Plants Journal. 7, 79-88.

DOI: https://doi.org/10.2979/NPJ.2006.7.1.79.

[26] Guo, Q., Brockway, D., Chen, X., 2017. Temperature-related sex allocation shifts in a recovering keystone species, Pinus palustris. Plant Ecology \& Diversity. 10(4), 303-310.

DOI: https://doi.org/10.1080/17550874.2017.1402968

[27] U.S. Fish and Wildlife Service, 2003. Recovery plan for the red-cockaded woodpecker (Picoides borealis): second revision. Atlanta, Georgia. pp. 296.

[28] Swanteson-Franz, R., Krofcheck, D., Hurteau, M., 2018. Quantifying forest carbon dynamics as a function of tree species composition and management under projected climate. Ecosphere. 9(4).

DOI: https://doi.org/10.1002/ecs2.2191

[29] Meldahl, R., Kush, J., Connor, K., 2006. Proceedings of the 13th biennial southern silvicultural research conference. Gen. Tech. Rep. SRS-92. Asheville, NC: U.S. Department of Agriculture, Forest Service, Southern Research Station.

[30] Ma, W., Zhou, S., Liang, J., Zhou, M., 2019. Coastal Alaska forests under climate change: What to expect? Forest Ecology and Management. 448, 432-444. DOI: https://doi.org/10.1016/j.foreco.2019.06.030.

[31] Prichard, S., Hessburg, P., Hagmann, K., Povak, N., Dobrowski, S., Hurteau, M., Kane, V., Keane, R., Kobziar, L., Kolden, C., North, C., Parks, S., Safford, H., Stevens, J., Yocom, L., Churchill, D., Gray, R., Huffman, D., Lake, F., Khatri-Chhetri, P., 2021. Adapting western North American forests to climate change and wildfires: 10 common questions. Ecological Applications. 31(8).

DOI: https://doi.org/e02433. 10.1002/eap.2433

[32] Seidl, R., Schelhaas, M.J., Rammer, W., et al., 2014 Increasing forest disturbances in Europe and their impact on carbon storage. Nature Climate Change. 4, 806-810.

DOI: https://doi.org/10.1038/nclimate2318

[33] Rother, M., Huffman, J.M., Harley, G., Verkerk, P.J., 2018. Cambial Phenology Informs Tree-Ring Analysis of Fire Seasonality in Coastal Plain Pine Savannas. Fire Ecology. 14, 164-185.

DOI: https://doi.org/10.4996/fireecology.140116418

[34] Stambaugh, M., Bigelow, S., Abadir, E., 2021. Linkages between forest growth, climate, and agricultural production are revealed through analysis of seasonally-partitioned longleaf pine (Pinus palustris Mill.) tree rings. Dendrochronologia. 65. 
DOI: https://doi.org/10.1016/j.dendro.2020.125801.

[35] Boyer, W., 1990. Pinus palustris, Mill. longleaf pine. In: Silvics of North America, vol. 1. Eds. RM Burns, BH Honkala. USDA Forest Service, Washington DC. pp. 405-412.

[36] Henderson, J., Grissino-Mayer, H., 2009. Climate-tree growth relationships of longleaf pine (Pinus palustris Mill.) in the Southeastern Coastal Plain, USA. Dendrochronologia. 27(1), 31-43.

DOI: https://doi.org/10.1016/j.dendro.2008.08.001.

[37] Soulé, P., Knapp, P., Maxwell, J., Mitchell, T., 2021. A comparison of the climate response of longleaf pine (Pinus palustris Mill.) trees among standardized measures of earlywood, latewood, adjusted latewood, and totalwood radial growth. Trees. 35, 1065-1074.

DOI: https://doi-org.aamu.idm.oclc.org/10.1007/ s00468-021-02093-z

[38] Edvardsson, J., Almevik, G., Lindblad, L., Linderson, H., Melin, K.M., 2021. How Cultural Heritage Studies Based on Dendrochronology Can Be Improved through Two-Way Communication. Forests. 12(8), 1047.

DOI: https://doi.org/10.3390/f12081047

[39] Lee, E.H., Wickham, C., Beedlow, P., Waschmann, R., Tingey, D., 2017. A likelihood-based time series modeling approach for application in dendrochronology to examine the growth-climate relations and forest disturbance history, Dendrochronologia. 45, 132144.

DOI: https://doi.org/10.1016/j.dendro.2017.08.003.

[40] Maxwell, J., Harley, G., Robeson, S., 2016. On the declining relationship between tree growth and climate in the Midwest United States: the fading drought signal. Climatic Change. 138, 127-142.

DOI: https://doi.org/10.1007/s10584-016-1720-3

[41] Torbenson, M., Stahle, D., Villanueva-Díaz, J., Cook, E., Griffin, D., 2016. The Relationship Between Earlywood and Latewood Ring-Growth Across North America. Tree-Ring Research. 72, 53-66. DOI: https://doi.org/10.3959/1536-1098-72.02.53.

[42] Ames, G., Vineyard, D., Anderson, D., Wright, J., 2015. Annual growth in longleaf (Pinus palustris) and pond pine (P. serotina) in the Sandhills of North Carolina is driven by interactions between fire and climate. Forest Ecology and Management. 340, 1-8. DOI: https://doi.org/10.1016/j.foreco.2014.12.020.

[43] Loudermilk, E., Hiers, J., Pokswinski, S., O'Brien, J., Barnett, A., Mitchell, R., 2016. The path back: oaks (Quercus spp.) facilitate longleaf pine (Pinus palustris) seedling establishment in xeric sites. Ecosphere. 7(6).
DOI: https://doi.org/10.1002/ecs2.1361

[44] Hart, J., O'Keefe, K., Augustine, S., McCulloh, K., 2020. Physiological responses of germinant Pinus palustris and $P$. taeda seedlings to water stress and the significance of the grass-stage. Forest Ecology and Management.

DOI: https://doi.org/10.1016/j.foreco.2019.117647.

[45] Prior, S., Runion, G., Mitchell, R., Rogers, H., Amthor, J., 1997. Effects of atmospheric CO2 on longleaf pine: productivity and allocation as influenced by nitrogen and water. Tree Physiology. 17(6), 397-405.

DOI: https://doi.org/10.1093/treephys/17.6.397

[46] Jose, S., Merritt, S., Ramsey, C., 2003. Growth, nutrition, photosynthesis and transpiration responses of longleaf pine seedlings to light, water and nitrogen. Forest Ecology and Management. 180(1-3), 335-344. DOI: https://doi.org/10.1016/S0378-1127(02)005832.

[47] Chen, X., Brockway, D., Guo, Q., 2018. Characterizing the dynamics of cone production for longleaf pine forests in the southeastern United States. Forest Ecology and Management. 429, 1-6.

DOI: https://doi.org/10.1016/j.foreco.2018.06.014.

[48] Guo, Q., Zarnoch, S., Chen, X., Brockway, D., 2016. Life cycle and masting of a recovering keystone indicator species under climate fluctuation. Ecosystem Health and Sustainability. 2(6).

DOI: https://doi.org/10.1002/ehs2.1226

[49] Boyer, W., 1997. Long-term changes in flowering and cone production by longleaf pine. In: Proceedings of the ninth biennial southern silvicultural research conference. Asheville, NC: U.S. Department of Agriculture, Forest Service, Southern Research Station.

[50] Chen, X., Guo, Q., Brockway, D., 2016. Analyzing the complexity of cone production in longleaf pine by multiscale entropy. Journal of Sustainable Forestry. $35(2), 172-182$.

DOI: https://doi.org/10.1080/10549811.2015.1135294

[51] Chen, X., Brockway, D., Guo., Q., 2020. Burstiness of Seed Production in Longleaf Pine and Chinese Torreya. Journal of Sustainable Forestry. DOI: https://doi.org/10.1080/10549811.2020.1746914

[52] Costanza, J., Terando, A., McKerrow, A., Collazo, J., 2015. Modeling climate change, urbanization, and fire effects on Pinus palustris ecosystems of the southeastern U.S. Journal of Environmental Management. 151, 186-199.

DOI: https://doi.org/10.1016/j.jenvman.2014.12.032.

[53] Haymes, K., Fox, G., 2012. Variation among individuals in cone production in Pinus palustris (Pinaceae). 
American Journal of Botany. 99, 640-645.

DOI: https://doi-org.aamu.idm.oclc.org/10.3732/ ajb. 1100339

[54] Gallagher, M., Campbell, D., 2020. Pollinator visitation rate and effectiveness vary with flowering phenology. American Journal of Botany. 107(3), 445455.

[55] Evans, E., Smith, C., Gendron, R., 1989. Timing of reproduction in a prairie legume: seasonal impacts of insects consuming flowers and seeds. Oecologia. 78, 220-230.

DOI: https://doi.org/10.1007/BF00377159

[56] Panchen, Z., Johnston, M., 2018. Shifts in pollen release envelope differ between genera with non-uniform climate change. American Journal of Botany. 105(9), 1568-1576.

[57] Akiko, S., Dave, K., 2021. Delayed fertilization facilitates flowering time diversity in Fagaceae. Philosophical Transactions of the Royal Society Biological Sciences.

DOI: http://doi.org/10.1098/rstb.2021.0115

[58] Brockway, D., 2015. Longleaf Pine Cone Prospects for 2015 and 2016.

[59] Chen, X., Guo, Q., Brockway, D., 2017. Power laws in cone production of longleaf pine across its native range in the United States. Sustainable Agriculture Research. 6(4), 64-73.

[60] Chen, X., Brockway, D., Guo, Q., 2016. Entropy dynamics in cone production of longleaf pine forests in the southeastern United States. Mathematical and Computational Forestry \& Natural-Resource Sciences. 8(2), 11-15.

[61] Whelan, A., Starr, C., Staudhammer, H., Loescher, Mitchell, R., 2015. Effects of drought and prescribed fire on energy exchange in longleaf pine ecosystems. Ecosphere. 6(7), 128.

DOI: http://dx.doi.org/10.1890/ES15-00111.1

[62] Johnsen, K., Creighton, J., Maier, C., 2015. Longleaf pine grown in Virginia: a provenance test. In Proceedings of the 17th biennial southern silvicultural research conference. Asheville, NC: U.S. Department of Agriculture, Forest Service, Southern Research Station.

[63] Peters, V., Gelderman, M., Visscher, D., 2017. Resiliency in masting systems: Do evolved seed escape strategies benefit an endangered pine? Ecosphere. $8(9)$.

DOI: https://doi.org/10.1002/ecs2.1928

[64] Solbreck, C., Knape, J., 2017. Seed production and predation in a changing climate: new roles for resource and seed predator feedback? Ecology. 98.
DOI: https://doi.org/10.1002/ecy.1941

[65] Linhart, Y., Moreira, X., Snyder, M., Mooney, K., 2014. Variability in seed cone production and functional response of seed predators to seed cone availability: support for the predator satiation hypothesis. Journal of Ecology. 102, 576-583.

DOI: https://doi.org/10.1111/1365-2745.12231

[66] Bogdziewicz, M., Marino, S., Bonal, R., Zwolak, R., Steele, M., 2018. Rapid aggregative and reproductive responses of weevils to masting of North American oaks counteract predator satiation. Ecology. 99.

DOI: https://doi.org/10.1002/ecy.2510

[67] Espelta, J., Arias-LeClaire, H., Fernandez-Martınez, M., Doblas-Miranda, E., Munoz, A., Bonal, R., 2017. Beyond predator satiation: Masting but also the effects of rainfall stochasticity on weevils drive acorn predation. Ecosphere. 8(6).

DOI: https://doi.org/10.1002/ecs2.1836

[68] Soler, R., Espelta, J., Lencinas, M., Peri, P., Pastur, G., 2017. Masting has different effects on seed predation by insects and birds in antarctic beech forests with no influence of forest management. Forest Ecology and Management. 400, 173-180.

[69] Boyer, W., 1964. Longleaf seed losses to animals on burned seedbeds. Restoration Note SO-6. US Department of Agriculture Forest Service, Southern Forest Experiment Station, New Orleans, Louisiana.

[70] Boyer, W., 1964. Longleaf pine seed predators in southwest Alabama. J. For. 62, 481-484.

[71] Gemmer, E., 1928. Black ants as destroyers of longleaf pine seedlings. Naval Stores Rev. 38(7), 25.

[72] Stephenson, G., Goodrum, P., Packard, R., 1963. Small rodents as consumers of pine seed in east Texas uplands. Journal of Forestry. 61, 523-526.

[73] Willis, J., Schnake, D., Wetzstein, B., Yow, J., Guinto, D., Ulrich, S., DePerno, C., Lashley, M., 2019. Seed Depredation Negates the Benefits of Midstory Hardwood Removal on Longleaf Pine Seedling Establishment. Restoration Ecology.

DOI: https://doi.org/10.1111/rec.12951

[74] Obeso, J., 2002. The costs of reproduction in plants. New Phytologist. 155, 321-348.

DOI: https://doi-org.aamu.idm.oclc.org/10.1046/ j.1469-8137.2002.00477.x

[75] Reznick, D., 1985. Costs of Reproduction: An Evaluation of the Empirical Evidence. Oikos. 44(2), 257267.

DOI: https://doi.org/10.2307/3544698

[76] Berdanier, A., Clark, J., 2016. Divergent reproductive allocation trade-offs with canopy exposure across tree species in temperate forests. Ecosphere. 7(6). 
DOI: https://doi.org/10.1002/ecs2.1313

[77] Liu, W., Pennings, S.C., 2019. Self-thinning and size-dependent flowering of the grass Spartina alterniflora across space and time. Functional Ecology. 33, 1830- 1841.

DOI: https://doi-org.aamu.idm.oclc.org/10.1111/13652435.13384

[78] Wenk, E., Falster, D., 2015. Quantifying and understanding reproductive allocation schedules in plants. Ecology and Evolution. 5, 5521-5538.

DOI: https://doi.org/10.1002/ece3.1802

[79] Lauder, J., Moran, E., Hart, S., 2019. Fight or flight? Potential tradeoffs between drought defense and reproduction in conifers. Tree Physiology. 39(7), 10711085.

DOI: https://doi-org.aamu.idm.oclc.org/10.1093/treephys/tpz031

[80] Merganičová, K., Merganič, J., Lehtonen, A., Vacchiano, G., Ostrogović Sever, M.Z., Augustynczik, A., Grote, R., Kyselová, I., Mäkelä, A., Yousefpour, R., Krejza, J., Collalti, A., Reyer, C., 2019. Forest car- bon allocation modelling under climate change. Tree Physiology. 39(12), 1937-1960.

DOI: https://doi-org.aamu.idm.oclc.org/10.1093/treephys/tpz105

[81] Patterson, T., Knapp, P., 2016. Stand Dynamics Influence Masting/Radial Growth Relationships in Pinus palustris Mill. Castanea. 81(4), 314-322.

DOI: https://doi.org/10.2179/16-085

[82] Patterson, T., Knapp, P., 2018. Longleaf pine cone-radial growth relationships in the southeastern U.S.A. Dendrochronologia. 50, 134-141. DOI: https://doi.org/10.1016/j.dendro.2018.05.006.

[83] Hoch, G., Richter, A., Korner, C., 2003. Non-structural carbon compounds in temperate forest trees. Plant, Cell \& Environment. 26, 1067-1081.

DOI: https://doi.org/10.1046/j.0016-8025.2003.01032.x

[84] Keyes, C., Gonzalez, R.M., 2015. Climate-influenced ponderosa pine (Pinus ponderosa) seed masting trends in western Montana, USA. Forest Systems. 24(1).

DOI: https://doi.org/10.5424/fs/2015241-05606. 